\title{
MicroRNAs and prostate cancer
}

\author{
Valeria Coppola ${ }^{1}$, Ruggero De Maria ${ }^{1,2}$ and Désirée Bonci ${ }^{1}$
}

${ }^{1}$ Department of Hematology, Oncology and Molecular Medicine, Istituto Superiore Sanità, viale Regina Elena 299, 00161 Rome, Italy ${ }^{2}$ Department of Experimental Oncology, Mediterranean Institute of Oncology, via Penninazzo 7, 95029 Viagrande, Catania, Italy

(Correspondence should be addressed to V Coppola; Email: valeria.coppola@iss.it)

\begin{abstract}
Despite much progress in prostate cancer management, new diagnostic, prognostic and therapeutic tools are needed to predict disease severity, choose among the available treatments and establish more effective therapies for advanced prostate cancer. In the last few years, compelling evidence has documented the role of microRNAs as new broad-spectrum oncogenes or tumour suppressor genes, thus their use as diagnostic, prognostic and therapeutic biomolecules is envisaged. This review extensively and critically summarizes the current knowledge about microRNA deregulation in prostate cancer disease, underlining present limits and future perspectives.
\end{abstract}

Endocrine-Related Cancer (2010) 17 F1-F17

\section{MicroRNAs: new actors in the cancer scene}

In recent years, the discovery of microRNAs has laid a new layer of complexity over the mechanisms regulating gene expression and function (He \& Hannon 2004, Chen \& Rajewsky 2007). MicroRNAs (miRNAs or miRs) are endogenous non-coding RNAs that can interfere with protein expression either by inducing the cleavage of specific target mRNAs or, in most cases, by inhibiting their translation (Bartel 2004). Thus, miRs offer a fast fine-tuning and energy-saving mechanism for post-transcriptional control of protein expression. Mature miRs are evolutionarily conserved 22-nt single-stranded RNAs resulting from a multistep processing of longer precursor molecules. miR genes are generally endowed with a Pol II promoter driving their transcription (Lee et al. 2004); alternatively, they are located in intronic sequences of host genes with which they are co-transcribed and excised by splicing events (Rodriguez et al. 2004). The primary transcripts (pri-miRs) can be thousands of nucleotides long and can contain the precursors of several clustered miRs. The endonucleolytic cleavage by the nuclear enzyme Drosha produces $\sim 70$-nt hairpin structures

This paper is one of 6 papers that form part of a special Focus Section on microRNAs. The Guest Editors for this section were Professor Alfredo Fusco, Naples, Italy, and Professor Carlo M Croce, Columbus, $\mathrm{OH}$, USA. called pre-miRs (Lee et al. 2003). These molecules are then transported to the cytoplasm and are further processed by the ribonuclease Dicer into doublestranded RNAs containing the mature $\mathrm{miR}$ and its bulged antisense sequence (miR*; Hutvagner et al. 2001, Ketting et al. 2001). Finally, the mature miR is selectively incorporated into the RNA-induced silencing complex (RISC) where it elicits the silencing of specific target mRNAs which are recognized by partial complementarity with sequences located in the $3^{\prime}$ UTR (Peters \& Meister 2007). Given the imperfect nature of these interactions, each miR can bind several different mRNAs and each mRNA can be targeted by multiple miRs, thus implying the existence of an intricate network of gene expression control (Lewis et al. 2005).

A rapidly increasing number of physiological processes are now known to be regulated by miRs, which are progressively found to be involved in the regulation of cellular functions ranging from maintenance of stemness to differentiation and tissue development, and from cell cycle to apoptosis and metabolism (Bushati \& Cohen 2007, Stefani \& Slack 2008, Gangaraju \& Lin 2009). Thus, it is intuitive that the aberrant expression of miRs can deeply impact on the multiple features of cell biology, ultimately resulting in complex pathological events such as infective (Baltimore et al. 2008, Cullen 2009), cardiovascular (Latronico \& Condorelli 2009) and neurodegenerative diseases (Bushati \& Cohen 2008), as well as cancer. 
The hypothesis that miRs can be regarded as new broad-spectrum oncogenes or tumour suppressor genes has opened a revolutionary field of research with exciting diagnostic and therapeutic perspectives. The compelling hint of a widespread miR deregulation in cancer pathogenesis came from the analysis of the genomic distribution of $186 \mathrm{miR}$ genes (Calin et al. 2004). In this study, it was demonstrated that more than half of them mapped in cancer-associated genomic regions, namely in chromosomal sites prone to deletions, amplifications or recombinations. These aberrations can result in miR down- or up-regulation, conferring selective advantages to mutated cells. Additional mechanisms of miR deregulation include altered expression of miRs as a consequence of excessive or deficient processing (Karube et al. 2005, Sugito et al. 2006); aberrant transcription of the precursors by epigenetic silencing of miR promoters (Saito et al. 2006, Lujambio et al. 2007) or as a result of the activity of oncogenic transcription factors (O'Donnell et al. 2005, Chang et al. 2008); and more rarely, point mutations in mature miRs or in target sequences that can interfere with normal target recruitment (Iwai \& Naraba 2005, Mayr et al. 2007).

In order to determine the ultimate effect of these events on miR expression, several platforms have been developed to characterize the full miRNome of cells. Better than complex mRNA profiles, distinct signatures of miRs seem to distinguish different tissues and cells of cancerous or normal origin ( $\mathrm{Lu}$ et al. 2005), thus offering a promising tool to individuate patterns of miR expression that might hopefully gain diagnostic and/or prognostic significance. Besides potential roles in diagnosis and prognosis, these small molecules stand as candidate therapeutic tools: many strategies are being developed to dampen or restore miR levels, thus offering the possibility to interfere at one stroke with multiple molecules or pathways deregulated in tumours.

\section{Prostate cancer: a complex scenario for miR action}

In developed western countries, prostate cancer is the most common malignant tumour in men, and is the second highest cause of cancer mortality after lung tumours (Gronberg 2003). Clinically, prostate cancer is diagnosed as local or advanced, and treatments range from surveillance to radiotherapy, radical prostatectomy or androgen-deprivation treatment. Androgen ablation, the mainstay for management of advanced prostate cancer, reduces symptoms in about $70-80 \%$ of patients, but most tumours relapse within 2 years to an incurable hormone-independent state, which is ultimately responsible for prostate cancer mortality (Damber \& Aus 2008). The regulatory mechanisms that cause this transition remain largely unknown, and to date, no effective therapy for androgen-independent prostate cancer has been developed.

On the contrary, for early-stage clinically localized disease, radical prostatectomy is generally curative. Nevertheless, treatment is often deferred with active monitoring, particularly in older men. This approach is based on the assumption that many prostate tumours are indolent and progress slowly relative to the patient's life expectancy (Wu et al. 2004). At present, the choice of the best treatment for clinically localized prostate cancer is not trivial, because radical surgery and radiotherapy do not offer a clear survival advantage in some patients, and treatment often results in a worse quality of life. During the last 20 years, prostatespecific antigen (PSA) testing has resulted in increased detection of early-stage prostate cancer: while some patients are cured of life-threatening disease, there are concerns about over-treatment and related morbidity (Loeb \& Catalona 2007). In fact, serum PSA level, primary tumour stage and Gleason grade do not reliably predict outcome for individual patients. Therefore, the identification of indicators of aggressiveness would be helpful in guiding therapeutic decisions, by distinguishing individuals with potentially lifethreatening disease for whom treatment is actually necessary. Diagnostic, prognostic and therapeutic molecules are needed to predict disease severity, choose among available treatments and establish more effective ones for advanced prostate cancer. In this complex scenario, some miRs could find their role.

\section{miR profiling in prostate cancer}

miR profiles of different tissues have been reported to be highly informative and more predictive than mRNA characterization to such an extent that poorly differentiated tumours of uncertain origin might be classified on the basis of miR expression (Lu et al. 2005). Nevertheless, in prostate cancer the effort of tracing a clear miR profile has proven inconclusive.

At present, much controversy is still present in the literature: conflicting results are often segregating different datasets, possibly because of the study design, underestimated treatments of the patients, methods of sample collection, presence of contaminating cells, and sensitivity and specificity of the platforms used. Table 1 offers an overview of such an inconsistency by summarizing miRs up- or down-regulated in 
Table 1 An overview of miR data inconsistency, by summarizing miRs up $(\uparrow)$ - or down ( $\downarrow$ )- regulated in prostate cancer disease, as reported in broad-spectrum miR profiles or in studies focused on single miRs. Only the miRs described as aberrantly expressed in at least two different studies are included in the list

\begin{tabular}{|c|c|c|c|c|c|c|}
\hline & Volinia & Ambs & Porkka & Ozen & Tong & Others \\
\hline let-7a & $\downarrow$ & & $\downarrow$ & & $\uparrow$ & \\
\hline let-7b & & $\downarrow$ & $\downarrow$ & $\downarrow$ & & \\
\hline let-7c & & & $\downarrow$ & $\downarrow$ & & \\
\hline let-7d & $\uparrow$ & & $\downarrow$ & $\downarrow$ & & \\
\hline let-7f & & & $\downarrow$ & $\downarrow$ & & \\
\hline let- $7 \mathrm{~g}$ & & & $\downarrow$ & $\downarrow$ & & \\
\hline let-7i & $\uparrow$ & $\uparrow$ & & $\downarrow$ & & \\
\hline miR-100 & & & $\downarrow$ & & $\downarrow$ & \\
\hline$m i R-125 a$ & & $\uparrow$ & $\downarrow$ & $\downarrow$ & & \\
\hline$m i R-125 b$ & & & $\downarrow$ & $\downarrow$ & $\downarrow$ & $\uparrow$ \\
\hline$m i R-128$ & $\downarrow$ & $\downarrow$ & & & & \\
\hline$m i R-141$ & & & & & $\uparrow$ & $\uparrow$ \\
\hline $\operatorname{miR}-143$ & & & $\downarrow$ & & $\downarrow$ & \\
\hline miR-145 & & & $\downarrow$ & & $\downarrow$ & \\
\hline $\operatorname{miR}-146$ & $\uparrow$ & & & & & $\downarrow$ \\
\hline$m i R-148$ & $\uparrow$ & & $\downarrow$ & & & \\
\hline $\operatorname{miR}-16$ & $\uparrow$ & & $\downarrow$ & $\downarrow$ & & $\downarrow$ \\
\hline $\operatorname{miR}-181$ & $\uparrow$ & $\uparrow$ & & & & \\
\hline miR-184 & $\uparrow$ & & $\uparrow$ & & & \\
\hline$m i R-195$ & $\uparrow$ & & $\downarrow$ & & & \\
\hline$m i R-196$ & $\uparrow$ & $\uparrow$ & & & & \\
\hline miR-198 & $\uparrow$ & & $\uparrow$ & & & \\
\hline$m i R-199 a$ & $\uparrow$ & & $\downarrow$ & & & \\
\hline miR-205 & & $\downarrow$ & $\downarrow$ & & $\downarrow$ & $\downarrow$ \\
\hline miR-20a & $\uparrow$ & & & & $\uparrow$ & $\uparrow$ \\
\hline$m i R-21$ & $\uparrow$ & & & & & $\uparrow$ \\
\hline$m i R-218-2$ & $\downarrow$ & $\downarrow$ & & & & \\
\hline$m i R-221$ & & $\downarrow$ & $\downarrow$ & & $\downarrow$ & $\uparrow$ \\
\hline miR-222 & & & $\downarrow$ & & $\downarrow$ & $\uparrow$ \\
\hline$m i R-23 b$ & & & $\downarrow$ & & $\downarrow$ & $\downarrow$ \\
\hline miR-25 & $\uparrow$ & $\uparrow$ & & & $\uparrow$ & \\
\hline$m i R-26$ & $\uparrow$ & $\uparrow$ & $\downarrow$ & $\downarrow$ & & \\
\hline miR-27a & $\uparrow$ & & $\downarrow$ & & & \\
\hline miR-29 & $\uparrow$ & & $\downarrow$ & $\downarrow$ & & \\
\hline$m i R-30 a$ & & & $\downarrow$ & $\downarrow$ & & \\
\hline$m i R-30 b$ & & & $\downarrow$ & $\downarrow$ & & \\
\hline$m i R-30 c$ & $\uparrow$ & & $\downarrow$ & $\downarrow$ & & \\
\hline$m i R-32$ & $\uparrow$ & $\uparrow$ & & & & \\
\hline$m i R-345$ & & $\downarrow$ & $\uparrow$ & & & \\
\hline miR-34a & $\uparrow$ & & & $\downarrow$ & & $\downarrow$ \\
\hline$m i R-370$ & & $\uparrow$ & $\uparrow$ & & & \\
\hline$m i R-449$ & & $\uparrow$ & & & & $\downarrow$ \\
\hline miR-92 & $\uparrow$ & $\uparrow$ & $\downarrow$ & & & \\
\hline$m i R-93$ & $\uparrow$ & $\uparrow$ & & & & \\
\hline$m i R-99 b$ & & $\uparrow$ & & $\downarrow$ & & \\
\hline
\end{tabular}

prostate cancer, as reported in broad-spectrum miR profiles or in studies focused on single miRs. miRs described as aberrantly expressed in at least two different studies are included in the list.

The opposite expression of some miRs reported in different studies of prostate tumours mirrors the controversial premises of miRs' overall expression in cancer. In fact, some studies state a widespread down-regulation of miRs in tumours ( $\mathrm{Lu}$ et al. 2005), consistently with a documented role of miRs in terminal differentiation and a general tendency of tumour cells to a more anaplastic state. Other studies, like the one conducted by Volinia et al. (2006) report on a cancer miR signature composed mostly by overexpressed miRs. By comparing total RNA extracted from 363 solid cancers and 177 normal tissues (in regard to prostate, 56 tumours and 7 tissues from non-cancerous individuals), Volinia's study 
verified a general up-regulation of miRs in cancer: specifically, $39 \mathrm{miRs}$ were up-regulated and $6 \mathrm{miRs}$ were down-regulated in prostate cancer. These results were in partial agreement with a more focused study conducted with a similar experimental setting by Ambs et al. (2008) in which total RNA extracted from 60 macrodissected prostate cancers and 16 surrounding non-tumour tissues was analyzed. Both studies found an up-regulation of $m i R-32, m i R-26 a, m i R-196 a$, miR-181a, miR-25, miR-93, miR-92 and let-7i and a down-regulation of $m i R-218$ and $m i R-128$. Moreover, Ambs et al. identified some miRs associated with extraprostatic extension of the tumours, including $m i R-101, m i R-30 c$ and $m i R-195$, which were also part of the prostate cancer signature described by Volinia et al. The general overexpression of miRs in prostate cancer was also supported by a computational study that verified a reduced abundance of putative miR targets in human prostate tumours by comparing three different gene expression datasets (Sun et al. 2009a).

Different results were shown by other groups, who observed a down-regulation of miRs in prostate cancer (Porkka et al. 2007). Porkka et al. analyzed small RNA obtained from 6 prostate cancer cell lines, 9 prostate cancer xenografts and 13 clinical prostate tissues, specifically 4 benign prostatic hyperplasia (BPH), 5 untreated prostate carcinomas and 4 hormone-refractory prostate carcinomas. A preliminary analysis showed that prostate cancer cell lines and xenografts were clustered by miR expression in nodes correlating with the androgen receptor status. Moreover, a significant association was described between miR levels and the copy number of miR loci reported in previous array comparative genomic hybridization (aCGH) datasets (Saramaki et al. 2006). The comparison of the clinical samples identified 51 miRs differentially expressed, specifically 37 downregulated and 14 up-regulated in carcinoma samples versus the BPH group; 15/37 and 6/14 were altered only in hormone-refractory carcinomas. The miR expression pattern obtained by Porkka et al. was different, if not reversed, from Volinia's \& Ambs' profiles: only the up-regulation of $m i R-184$ and miR-198 and the down-regulation of let-7a were in agreement with Volinia's and the down-regulation of $m i R-205$ and $m i R$-221 with Ambs'. On the contrary, Porkka's profile discretely overlapped that generated by Ozen et al. (2008). In the latter study, the authors compared 16 prostate cancer tissues and 10 normal prostate tissues and observed a widespread downregulation of miRs in human prostate cancer: among the 85 detectable miRs, 76 were down-regulated, with a tendency of a more global down-regulation of miRs in the cases with early PSA recurrence. As aforementioned, several miRs were confirmed as down-regulated by Porkka \& Ozen, including the let-7 family (let-7a, let-7b, let $-7 c$, let $-7 d$ and let-7g), miR-16, miR-23a/b, miR-99, miR-125a/b, miR-29 a/b and $\mathrm{miR}-30 \mathrm{a} / \mathrm{b} / \mathrm{c}$.

More recently, Tong et al. analyzed 40 formalin-fixed paraffin-embedded prostatectomy specimens with $\mathrm{T} 2 \mathrm{a} / \mathrm{b}$ stage tumours, including 20 with biochemical relapse within 2 years of prostatectomy and 20 without relapse for 10 years. For each specimen, areas of malignancy were microdissected and compared to uninvolved areas (Tong et al. 2009). The main findings of this study were the down-regulation of $m i R-23 b$, $-100,-145,-221$ and -222 (in agreement with Porkka's analysis) and the tendency of early relapse tumours to display a distinguished miR signature (particularly, $m i R-135 b$ and -194 overexpression).

Given these controversial results, it stands that a conclusive miR profile in prostate cancer cannot be drawn. Even though microarray technology applied to miRs offers an appealing tool to set up patient-tailored treatments, the high-throughput nature of these experiments and the relative infancy of miR studies means that results should be interpreted with caution. The successful execution of such studies requires close collaboration between surgeons, pathologists, molecular biologists and bioinformatics' experts because the complexity of biological systems implies various levels at which both interexperimental and intraexperimental variability can occur.

First, mere technical issues can deeply impact on results: the use of total RNA or enriched small RNA can lead to differences in sensitivity and therefore in variability in detectable miRs and in relative percentages of deregulated miRs. Also, the design of probes able to detect both immature and mature miRs can give a distorted view of the active miRs if any alteration of the processing occurs.

Secondly, the quality of starting material is pivotal: tissue handling and choice can drastically affect the interpretation of microarray data. Even though miRs are known to be more stable than mRNA, different methods and timing of tissue storage can result in different levels of miR expression. In this regard, the documented influence of hypoxic stress on miR expression (Kulshreshtha et al. 2007) imposes the consideration of a relevant variable, which can bias results for the pre-existence of a hypoxic component of the tumour, which is more likely in cancers of bigger volume. This issue adds further complexity to the problem of tissue heterogeneity. In tumour samples, 
heterogeneity derives from high genetic instability and from the contamination with other cell types that can be present in the tissue in varying degrees, such as fibroblasts and myoepithelial, endothelial and inflammatory cells. Moreover, in early-stage focal lesions, tumour cells can be surrounded by a majority of normal cells. On the other hand, a very careful choice of healthy reference tissue is crucial, as this can be contaminated by neoplastic tissue or be the mirror of a hyperplastic stage that could be characterized by a distinct miR signature. In this regard, the analysis of laser-capture microdissected areas of tumour and normal cells offers the most promising solution to these kind of drawbacks.

Thirdly, study design and patient selection can account for considerable variability in results, not only for eventual intrinsic differences in tumour stage and grade but also for probable influences of extrinsic treatments such as radiotherapy (Josson et al. 2008, Shin et al. 2009) or androgen deprivation on global and specific miR expression.

Finally, in such a novel and rapidly developing field it cannot be excluded that previously unconsidered mechanisms and variables might need to be elucidated in order to gain better data consistency.
In the following paragraphs, an up-to-date overview of the miRs whose physiological role in prostate cancer development and progression has been specifically investigated is presented. Figure 1 summarizes these miRs, with their targets and their functions, such as those described in prostate cancer studies. The inconsistency of some deregulations with expression profile results has been discussed above and is summarized in Table 1. The following description includes miRs whose alterations have been correlated with genetic alterations and which eventually result in epigenetic reprogramming, miRs acting downstream of transcription factors and miRs whose deregulation has been implicated in prostate cancer progression through the acquisition of invasive features and/or androgen independence.

\section{Focusing on single miRs: starting from genetics}

It is widely accepted that tumour initiation and progression occur through the accumulation of genetic aberrations leading to deregulated expression of genes located in amplified or deleted regions, namely classical oncogenes or tumour suppressor genes. It is now increasingly clear that the same concept can be

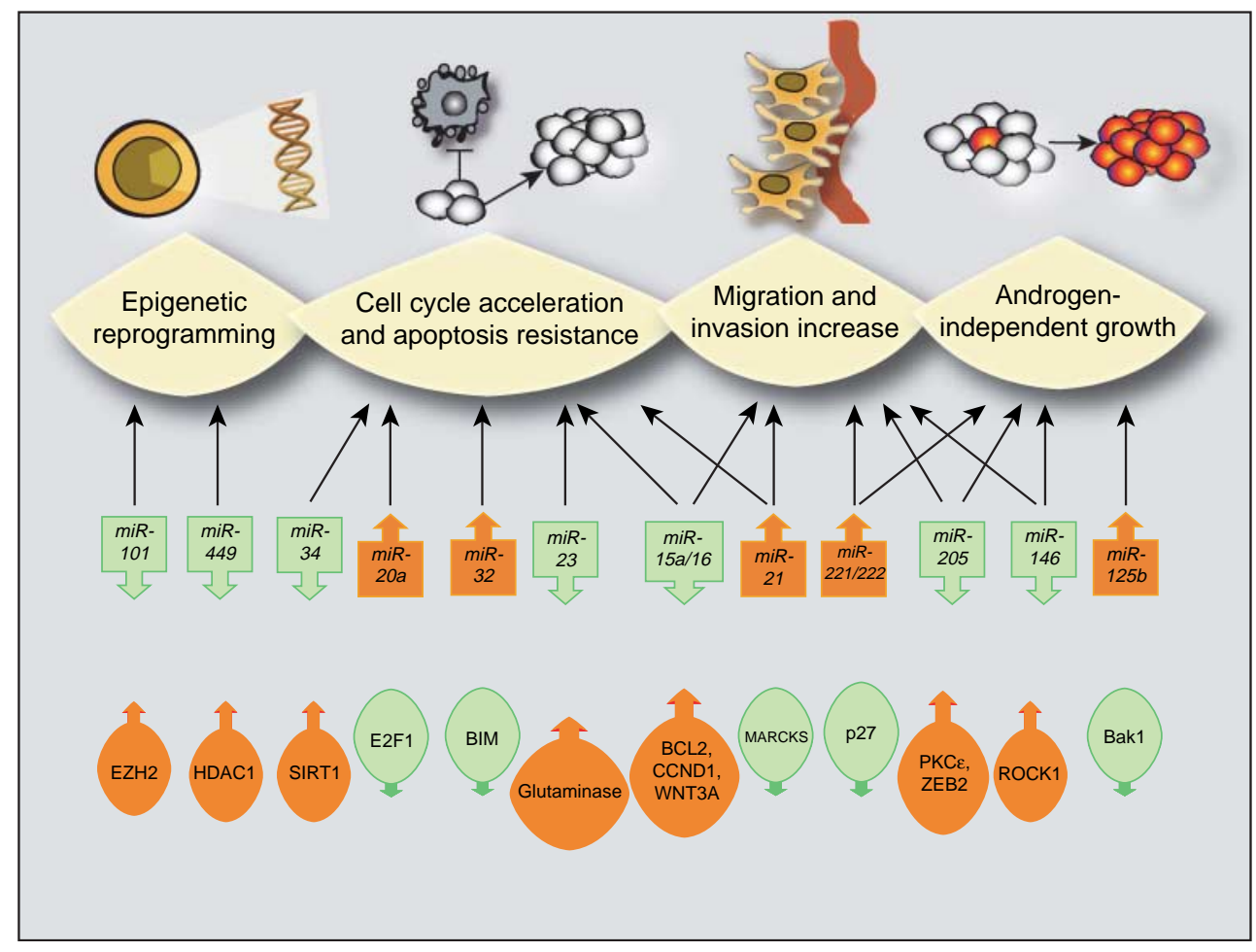

Figure $1 \mathrm{miRs}$ whose physiological role in prostate cancer has been thoroughly investigated. miR targets and functions, such as those described in prostate cancer studies, are shown. 
applied to miR genes, which have already been found to be enriched in known cancer-associated genomic regions at the onset of their discovered function in cancer pathogenesis (Calin et al. 2004).

Chromosomal $\mathrm{CGH}$ and loss of heterozygosity $(\mathrm{LOH})$ studies have verified that in early-stage tumours genomic DNA losses prevail over gains, with $6 \mathrm{q}, 8 \mathrm{p}$, $10 q, 13 q, 16 q$ and $17 p$ being implicated most often in these alterations. In hormone-refractory prostate cancer, LOH frequency raises three- to fourfold and chromosomal gains also become prevalent: amplifications at $7 \mathrm{p}, 7 \mathrm{q}, 8 \mathrm{q}$ and $\mathrm{Xq}$ are common late events associated with an aggressive phenotype (Visakorpi et al. 1995, Nupponen et al. 1998a,b, Porkka \& Visakorpi 2004, Saramaki et al. 2006). In particular, gain of the $8 \mathrm{q}$ region is the most frequent $(80-90 \%$ of cases) and huge chromosomal alteration in advanced prostate tumours, involving nearly the whole $8 \mathrm{q}$ arm. Even though more than one oncogene can be included in such an aberration (Reiter et al. 2000), c-MYC amplification at $8 \mathrm{q} 24$ is recognized as the main event related to prostate tumour progression. Few genes have been described as the main targets of losses of heterozygosity, including NKX33-1 at 8p21, PTEN at $10 \mathrm{q} 23.3$ and $K L F 5$ at 13q21 (Dong 2001). Despite the presence of two important tumour suppressor genes at $13 \mathrm{q}$, namely $B R C A 2$ and $R B 1$, no correlation between $\mathrm{LOH}$ and down-regulation of these genes has been observed (Latil et al. 1999, 2002). A detailed analysis of microsatellite markers on $13 \mathrm{q}$ identified a minimal region of loss of $800 \mathrm{~kb}$ at 13q14.2-q14.3 (Ueda et al. 1999, Yin et al. 1999, Chen et al. 2001). This allelic imbalance is observed in about $65 \%$ of prostate tumours and has been found to be associated with early biochemical relapse (Brookman-Amissah et al. 2007).

\section{$\operatorname{miR}-15 a / m i R-16$}

Interestingly, the above-mentioned region encompasses two miR genes, $m i R-15 a$ and $m i R-16$, frequently deleted or down-regulated in chronic lymphocytic leukaemia (Calin et al. 2002) and shown to induce apoptosis by post-transcriptional repression of the antiapoptotic protooncogene BCL2 (Cimmino et al. 2005).

Based on the hypothesis that these miRs might be the previously unidentified tumour suppressor genes in prostate cancer, our group investigated their expression and function in prostate (Bonci et al. 2008). By qPCR analysis of 20 prostate tumour-derived primary cultures compared to their normal counterpart and by in situ hybridization analysis of 15 prostate tumour biopsies, $m i R-15 a / m i R-16$ levels were found to be down-regulated in the vast majority of the cases (up to
$85 \%$ of the samples). By using the model of two prostate cell lines, the normal immortalized RWPE-1 cells and the prostate cancer LNCaP cells with reduced miR-15a/miR-16 levels, the functions and targets of these miRs were investigated. A stable lentivirusmediated sequestering of $m i R-15 a / m i R-16$ in RWPE-1 cells induced an increase in proliferation and migration in vitro and allowed these cells to form small tumour masses in nonobese diabetes/severe combined immunodeficiency (NOD/SCID) mice. On the contrary, lentivirus-mediated $m i R-15 \mathrm{a} / \mathrm{miR}-16$ reconstitution in LNCaP cells resulted in a dramatic apoptotic effect in vitro and in considerable regression of tumour xenografts in vivo. Moreover, antagomiR-15a/antagomiR-16 injection in normal prostates of BALB/C mice resulted in hyperplastic morphology of the gland, with alterations of normal acini architecture. These observations were, at least in part, explained by the evidence that $m i R-15 \mathrm{a} / \mathrm{miR}-16$ are able to post-transcriptionally repress the expression of BCL2, CCND1 (i.e. cyclin D1) and WNT3A, thus interfering with multiple oncogenic activities. BCL2 up-regulation has been described as a common event, especially in hormonerefractory prostate cancer, where it can support survival of cells in the absence of androgens (McDonnell et al. 1992, Colombel et al. 1993). CCND1 is a well-known promoter of cell proliferation and its regulation by $m i R-15 a / m i R-16$ is in line with the evidence of a more widespread role of these miRs in the control of cell cycle progression (Linsley et al. 2007, Liu et al. 2008). WNT3A has been implicated in prostate cancer pathogenesis by enhancing $\beta$-catenin stabilization and its transcriptional activity, as well as by activating pivotal oncogenic pathways such as v-akt murine thyoma viral oncogene homolog (AKT) and mitogenactivated protein kinase (MAPK) (Almeida et al. 2005, Yun et al. 2005). $\beta$-catenin stabilization leads to the transcription of several oncogenic genes (such as CCND1 itself, MYC, MMPs and endothelin) and, by acting as a co-activator of androgen receptor, it promotes its activity in the presence of low androgen levels (Schweizer et al. 2008). AKT and MAPK activation can also provide prostate cancer cells with survival and proliferation signals in a hormonedeprived environment (Yeh et al. 1999, Graff et al. 2000). Moreover, a recent report showed that miR-15a/miR-16 regulate vascular endothelial growth factor (VEGF) levels (Karaa et al. 2009), thus implying a role of these two miRs in the control of angiogenesis. In conclusion, several lines of evidence support the concept that $m i R-15 \mathrm{a} / \mathrm{miR}-16$ loss might contribute by different means to prostate cancer progression. 
$\operatorname{miR}-101$

$m i R-101$ is another miR for which genomic loss has been described as a causative mechanism of deregulation (Varambally et al. 2008). miR-101 loci on chromosome 1 (miR-101-1) and chromosome 9 (miR-101-2) were found to be somatically lost in $37.5 \%$ of clinically localized prostate cancer and $66.7 \%$ of metastatic disease. Moreover, according to public domain aCGH datasets, this event seems to be common to a broad range of cancer types. miR-101 overexpression in DU145 prostate cancer cells attenuated their proliferation in vitro and in vivo and markedly impaired their invasive potential. miR-101 decrease during prostate cancer progression was found to parallel an increase in enhancer of zeste homologue 2 (EZH2), which was demonstrated as a direct target of miR-101 (Varambally et al. 2008). The primary activity of $\mathrm{EZH} 2$, a master regulator of important cellular processes, is to trimethylate histone $\mathrm{H} 3$ lysine 27, thus leading to widespread gene silencing (Yu et al. 2007, Cao et al. 2008). EZH2 has been described as being overexpressed in many solid tumours, promoting cell proliferation, anchorage-independent growth and invasion. Nevertheless, the mechanism of its elevation is unclear so far. The deletion of $m i R-101$ may be the missing molecular link by which a genetic event can deeply impact on cell epigenetics.

\section{$\operatorname{miR}-449$}

Similarly, miR-449 has been reported to influence cell transcriptome by modulating histone deacetylase 1 (HDAC1) levels (Noonan et al. 2009). HDACs prevent transcription through the removal of acetyl groups from histones, thereby promoting chromatin condensation. The relevance of its overexpression in cancers is supported by the existence and the efficacy of HDAC inhibitors in clinical practice. HDAC1 has been described as overexpressed in up to $70 \%$ of prostate tumours (Weichert et al. 2008), and HDAC inhibitors proved effective in animal models of prostate cancer (Qian et al. 2007, Wedel et al. 2008). The levels of miR-449 were found to be lower in prostate tumours than in matched controls. Its reintroduction in PC3 prostate cancer cells resulted in growth arrest, apoptosis and a senescence-like phenotype (Weichert et al. 2008, Noonan et al. 2009). Reduction of $m i R-449$, putatively by loss of the prostate cancer susceptibility locus $5 \mathrm{q} 12$, may therefore contribute to HDAC1 increase and downstream epigenetic silencing.

\section{miR-34}

Apart from acting upstream of widespread transcriptional changes through the modulation of epigenetic processes, miRs can work downstream of master transcription factors and thereby mediate their functions. Several recent studies have implicated the $m i R$ 34 family of miRs in the p53 tumour suppressor network (Bommer et al. 2007, He et al. 2007). The expression of miR-34 is markedly induced by DNA damage and oncogenic stress in a p53-dependent manner. miR-34 activation can recapitulate the elements of p53 activity, inducing cell cycle arrest and apoptosis by the down-modulation of proteins such as CDK4, CDK6, cyclin D1, cyclin E2, E2F3 and BCL2 (Chang et al. 2007, Raver-Shapira et al. 2007, Tazawa et al. 2007). On the contrary, loss of $m i R-34$ can impair p53-mediated cell death. These effects have also been observed in prostate cancer, where miR-34 was found to be absent in androgen-refractory, p53-defective PC3 and DU145 cell lines. miR-34 reconstitution in PC3 cells impaired cell growth and camptothecin resistance (Fujita et al. 2008). Interestingly, $m i R-34$ also inhibits SIRT1, a gene that hinders p53-dependent apoptosis, promoting survival under genotoxic and oxidative stress (Yamakuchi et al. 2008). SIRT1 is elevated in a variety of cancer cells, including PC3 and DU145, where it contributes to chemoresistance. Therefore, $m i R-34$ participates in a positive feedback loop that enhances p53 activity by suppressing SIRT1. Its loss recapitulates, at least in part, the loss of p53.

\section{$\operatorname{miR}-23$}

Likewise, by targeting glutaminase, $m i R-23$ has been found to participate in the pro-tumourigenic network resulting from MYC overexpression, which is thought to be the most common alteration in prostate cancer. One of the effects of this up-regulation is the increase in oxygen consumption and the induction of mitochondrial mass and function (Li et al. 2005). Cancer cells depend on continued mitochondrial function for metabolism, including for glutaminolysis. Glutamine is a major source of energy and its catabolism provides nitrogen and carbon substrates for anabolic processes; on the other hand, glutamine catabolism produces the substrate for the synthesis of glutathione, which protects cells from reactive oxygen species. High MYC expression results in strong induction of mitochondrial glutaminase, the enzyme converting glutamine to glutamate. This effect was found to be mediated by MYC-induced miR-23 repression (Gao et al. 2009). According to Porkka's analysis, $m i R-23$ 
levels are reduced in prostate cancer, while elevated levels of MYC parallel glutaminase levels. Thus, $m i R-23$ loss may connect a genetic alteration to metabolic anomalies in cancer cells.

\section{miR-146}

Also belonging to the group of reduced miRs, $m i R-146$ was identified as more consistently downregulated in androgen-independent prostate cancer cell lines (including $\mathrm{LNCaP}-\mathrm{C} 81, \mathrm{LNCaP} \mathrm{C} 4-2 \mathrm{~B}$ and PC3) than in androgen-dependent cell lines (LNCaP and PC3-AR9; Lin et al. 2007). This finding was confirmed by fluorescent in situ hybridization analysis in human prostate cancer tissue arrays. miR-146 contribution to prostate cancer progression has been identified in its capacity to repress ROCK1 expression (Lin et al. 2008), a downstream effector of hyaluronan-mediated signalling on CD168 receptor. Hyaluronan is synthesized by stromal fibroblasts in response to paracrine factors produced by tumour cells, and this crosstalk is crucial for the development and progression of hormone-refractory prostate cancer. In particular, adhesion of tumour cells to host cell layers and subsequent transcellular migration are pivotal steps in cancer invasion and metastasis. ROCK1-mediated oncogenic mechanisms include the direct phosphorylation of myosin light chain, which leads to increased cell migration and invasion (Itoh et al. 1999), activation of AKT/ TOR/eIF4E signalling and increase in macrophage colony-stimulating factor (M-CSF) cytokine production to facilitate osteolytic metastasis (Bourguignon et al. 2003).

Interestingly, it has been demonstrated that miR-146 inhibits the translation of the SDF-1 receptor CXCR4, and that megakaryopoiesis is controlled by a cascade pathway, in which the promyleocytic leukemia zinc finger (PLZF) factor suppresses $m i R-146$ transcription and thereby activates CXCR4 translation (Labbaye et al. 2008). Although reported in a completely different system, this targeting may have pathogenic relevance in prostate cancer metastasis. As a matter of fact, haematopoietic cells home to bone during embryonic development; the chemokine SDF-1 (expressed by osteoblasts and endothelial cells) and its receptor CXCR4 play a key role in this process (Kucia et al. 2005). Increasing evidence is supporting the idea that the SDF-1/CXCR4 axis influences the formation of the premetastatic niche and the recruitment of endothelial progenitor cells at the primary tumour site with subsequent angiogenesis (Wang et al. 2006). Several different tumour types, including the osteotropic prostate and breast cancers, have been shown to overexpress CXCR4 (Mochizuki et al. 2004, Luker \& Luker 2006), possibly at the posttranscriptional level (Sun et al. 2003). In prostate cancer, CXCR4 protein expression is significantly elevated and its levels are associated with poor prognosis (Akashi et al. 2008). Thus, it is conceivable that miR-146 loss might contribute to enhanced prostate cancer aggressiveness by increasing multiple prometastatic proteins, including ROCK1 and CXCR4.

\section{miR-205}

Also described as implicated in migration control, $m i R-205$ was reported to be down-regulated in prostate cancer cell lines and in 23 of 31 prostate carcinomas compared to the untransformed RWPE-1 cell line and normal prostate tissues respectively (Gandellini et al. 2009). miR-205 restoration in DU145 prostate cancer cells resulted in marked morphological changes resembling a reverse epithelial-mesenchymal transition. Specifically, $m i R$-205-transfected cells tended to shift from a fibroblast-like elongated phenotype to a large, flattened, polygonal shape and to aggregate in tightly packed colonies. The enhanced cellular adhesion of these cells was confirmed by a strong increase in E-cadherin and $\beta$-catenin expression at cell-cell contacts. Consistently with a role in the negative control of epithelial-mesenchymal transition, an event preceding metastasis, $m i R-205$ reintroduction significantly reduced migratory and invasive capabilities of DU145 and PC3 cells. These effects were partially explained by $m i R-205$ targeting of PRKCE (PKCE) and ZEB2 mRNAs. The role of these molecules in prostate cancer progression is sustained by ZEB2-mediated repression of E-cadherin transcription (Peinado et al. 2007) and by PKC $\varepsilon$-induced increase in proliferation, apoptosis resistance and androgen independence (Wu \& Terrian 2002). Unexpectedly, $\mathrm{PKC} \varepsilon$ interference rather than ZEB2 interference produced a phenotype more reminiscent of the one observed in $m i R$-205-expressing cells. Interestingly, gene expression profile of DU145 transfected with $m i R-205$ precursor revealed a general induction of genes involved in the assembly of cell junctions and the down-regulation of several pro-tumourigenic factors, some of which have already been associated with prostate cancer progression, such as IL-6 (Culig et al. 2005), caveolin-1 (Williams et al. 2005), EZH2 (Varambally et al. 2002, Bracken et al. 2003), ERBB3 (Li et al. 2006), E2F1 and E2F5. 


\section{miR-21}

Although not extensively investigated in prostate cancer, $m i R-21$ is noteworthy as in the large-scale study conducted by Volinia et al. it was the only miR up-regulated in all the analyzed tumours, including breast, colon, lung, pancreas, prostate and stomach cancers. Additional studies demonstrated elevated $m i R-21$ expression in hepatocellular carcinomas (Kutay et al. 2006), ovarian cancer (Iorio et al. 2007, Nam \& Kim 2008), cervical carcinoma (Lui et al. 2007), multiple head and neck cancer cell lines (Tran et al. 2007), papillary thyroid carcinoma (Tetzlaff et al. 2007) and some other solid tumours. More recent studies indicate that $m i R-21$ is also up-regulated in leukaemic cancers (Fulci et al. 2007, Lawrie 2007, Jongen-Lavrencic et al. 2008, Navarro et al. 2008). Therefore, abundant $m i R-21$ may be a general feature of tumour cells.

In prostate cancer, $m i R-21$ was found to be elevated in PC3 and DU145 androgen-independent cell lines (Li et al. 2009). Blocking $m i R-21$ by antisense oligonucleotides did not affect proliferation, but it sensitized cells to staurosporine-induced apoptosis and impaired cell motility and invasion. In this study, myristoylated alanine-rich protein kinase $\mathrm{C}$ substrate (MARCKS) was identified as a new $m i R-21$ target in prostate cancer cells. Given the involvement of MARCKS in cellular processes such as cell adhesion, spreading, membrane trafficking and cell motility (Arbuzova et al. 2002), it is conceivable that the observed effects were due, at least in part, to modified MARCKS levels. However, lessons from other cancers suggest that a wider spectrum of genes might be altered in $m i R-21$-overexpressing cells. Validated targets of $m i R-21$ enclose several genes mainly implicated in suppressing cell migration and invasion, including PDCD4 (Asangani et al. 2008, Frankel et al. 2008), PTEN (Meng et al. 2007), TPM1 (Zhu et al. 2007), SPRY2 (Sayed et al. 2008) and the metalloprotease inhibitors TIMP3 and RECK (Gabriely et al. 2008).

\section{miR-221/miR-222}

Along with $m i R-21$, the two closely related $m i R-221$ and $m i R-222$ are among the most frequently overexpressed miRs in cancer. Several reports have consistently described the up-regulation of either one miR or both miRs in a wide spectrum of human tumours, including glioblastoma (Ciafre et al. 2005), melanoma (Felicetti et al. 2008), and hepatocellular carcinoma (Fornari et al. 2008), as well as in thyroid (Pallante et al. 2006), kidney and bladder (Gottardo et al. 2007), gastric (Kim et al. 2009), pancreatic
(Lee et al. 2007), ovarian (Dahiya et al. 2008) and prostate cancers (Galardi et al. 2007). In prostate cancer cell lines and primary tumour cells, an inverse correlation between the expression of $m i R-221 / m i R$ 222 and the cell cycle inhibitor p27 $7^{\mathrm{Kip} 1}$ (Galardi et al. 2007, Mercatelli et al. 2008) has been described. Consistently, ectopic introduction of $m i R-221 / m i R$ 222 in low expresser LNCaP cells strongly increased their growth potential by inducing a $G_{1}-S$ shift in the cell cycle, and it was able to enhance their clonogenicity in soft agar and their tumourigenicity in SCID mice. Conversely, anti-miR-221/222 treatment of high expresser PC3 cells impaired their colony-forming potential in vitro and reduced tumour growth in vivo (Mercatelli et al. 2008). The documented influence on the levels of CDK inhibitors $\mathrm{p} 27^{\mathrm{Kip} 1}$ and $\mathrm{p} 57^{\mathrm{Kip} 2}$ by $m i R-221 / m i R-222$ can easily explain the observed effects on cancer cell proliferation. In particular, $\mathrm{p} 27^{\mathrm{Kip} 1}$ is a well-established marker of poor prognosis in several human tumours, including prostate cancers. However, further studies are needed to unravel the role of $m i R-221 / m i R-222$ in the progression to androgen independence. A recent study comparing androgendependent and androgen-independent LNCaP cells has described $m i R-221 / m i R-222$ as massively increased in castration-resistant cells (Sun et al. 2009b). Overexpression of $m i R-221$ or $m i R-222$ in androgendependent LNCaP cells significantly reduced the dihydrotestosterone (DHT)-induced up-regulation of PSA expression and increased androgen-independent growth. Conversely, knocking down $m i R-221$ and $m i R-222$ in the hormone-resistant clone impaired the growth rate of these cells and restored the sensitivity to DHT in terms of PSA transcription and of hormonestimulated proliferation. Thus, increased miR-221/ $m i R-222$ levels seem to contribute to androgenindependent growth and to be necessary for maintaining the castration-resistant phenotype. Speculatively, this notion may fit together with the reported observation that androgens down-regulate $m i R-221 / m i R-222$ levels, thereby helping to explain the controversial low levels of these two miRs documented in microarray studies (Ambs et al. 2008). In the scenario of an early, hormone-dependent disease, androgens may play a protective role by keeping miR-221/miR-222 levels low. Loss of this restraint might accompany, as a cause or as an effect, prostate cancer progression.

\section{miR-125b}

In a similar effort to identify miRs associated with prostate cancer progression towards androgen independence, $m i R-125 b$ was described as up-regulated by 
androgens and overexpressed in androgen-independent LNCaP sublines compared to parental cells (Shi et al. 2007). These controversial findings suggest that androgen-independent regulation of $m i R-125 \mathrm{~b}$ may also exist. Similar to $m i R-221 / m i R-222$, transfection of synthetic miR-125b stimulated the growth of LNCaP cells in the absence of androgens, whereas anti-miR-125b inhibited the growth of androgenindependent cells. In this study, the pro-apoptotic Bak1 was identified as a target of miR-125b. Bak1 expression has also been reported to be associated with the progression of prostate cancer, with it being reduced in hormone-refractory tumours (Yoshino et al. 2006). However, as Bak1 interference did not significantly increase proliferation of prostate cancer cells, further studies are needed to elucidate the role of this miR. Overall, the oncogenic role of $m i R-125 b$ in prostate cancer progression needs further investigation as three miR expression profiles report it as downregulated in prostate cancer (Porkka et al. 2007, Ozen et al. 2008, Tong et al. 2009). Moreover, $m i R-125 b$ has been described as a tumour suppressor gene in human breast cancer, where it can negatively regulate the expression of both ERBB2 (HER2) and ERBB3 (HER3) (Scott et al. 2007). Although miRs can act as oncogenes or tumour suppressor genes in different cellular contexts, it is puzzling that increased expression of HER 2 has been reported in prostate cancer and considered to be a mechanism related to androgen independence (Craft et al. 1999).

\section{miR-32, miR-106b-25-93 and miR-126*}

$m i R-32$ gene and the cluster $m i R-106 \mathrm{~b} / \mathrm{miR}-25 / \mathrm{miR}-93$ are located in the intronic regions of $C 9$ orf5 and $M C M 7$ respectively. These miRs have been described as up-regulated in prostate cancer as a consequence of the overexpression of their host genes (Ambs et al. 2008). Whereas the role of C9orf5 in cancer is unknown, MCM7 amplifications had already been associated with prostate cancer (Ren et al. 2006). However, little is known about the functional relevance of these co-regulations, and further studies are needed to address whether the oncogenic effects of these amplifications are due to either the host genes or the miRs. miR-32 was found to inhibit the expression of BIM, a proapoptotic member of the BCL2 family, whose down-regulation can contribute to the resistance of tumour cells to death stimuli (Ambs et al. 2008). Likewise, the miR-106b cluster was found to play an antiapoptotic, growth inhibitory activity by suppressing E2F1 and p21/WAF1 (Ambs et al. 2008). E2F1 is also a target of $m i R-17-5 p$ and $m i R-20 a$, two miRs belonging to the $m i R-17-92$ cluster, which were found to be up-regulated in many tumours, including prostate (Volinia et al. 2006, Sylvestre et al. 2007).

Conversely, it has been demonstrated that $m i R-126^{*}$ deficiency in prostate cancer cells is due to poor expression of its host gene, EGF-like domain 7. The absence of $m i R-126^{*}$ results in high levels of its natural target prostein, a prostate antigen whose reduction impairs LNCaP cell migration and invasion (Musiyenko et al. 2008).

\section{MYC and miR: an attempt to weave a net}

In the last few years, both large-scale and focused studies have shed light on the identity of miRs whose deregulation might have a pathogenic significance in prostate cancer disease. In some cases, miR deregulations have been proposed or demonstrated as consequences of single genetic or epigenetic events occurring during tumour progression. However, it may be intriguing to wonder if a common upstream event might also contribute to widespread miR deregulation. In this regard, oncogenic transcription factors may amplify their effects by deregulating the activity of sets of miRs, and thereby indirectly influence a huge spectrum of targets. In particular, it is remarkable that several reports have demonstrated the existence of a tight link between miRs and MYC, albeit in experimental systems different from prostate. The c-MYC oncogenic transcription factor is pathologically activated in many human malignancies (Adhikary \& Eilers 2005, Meyer \& Penn 2008) including prostate cancer, where amplification of the 8q region is one of the most frequent somatic lesions (Jenkins et al. 1997) and c-MYC activity is known to induce androgen-independent prostate cancer growth (Bernard et al. 2003).

In lymphoma cells, c-MYC was found to directly activate the expression of the miR-17-92 cluster, a group of six miRs, including the above-mentioned $m i R-17-5 p$ and $m i R-20$, which is known to contribute to lymphomagenesis and to be involved in many human cancers by promoting cell proliferation, suppressing apoptosis and inducing angiogenesis (Mendell 2008). Interestingly, a later report documented a MYC-induced widespread down-regulation of miRs by direct binding of the transcription factor to promoters or conserved regions upstream of the regulated miRs (Chang et al. 2008). The functional significance of this down-regulation was demonstrated by the evidence that enforced expression of repressed miRs diminished the tumourigenic potential of lymphoma cells in vivo. The list of down-regulated 
miRs included members of the let-7 family, miR-15a, miR-16, miR-22, miR-26, miR-29, miR-30, miR-34, $m i R-146$, miR-150 and miR-195. Moreover, c-MYC was reported to activate the expression of $m i R-106 \mathrm{~b}$ (Sampath et al. 2009) and to induce EZH2 overexpression by repressing $m i R-26$ (Sander et al. 2008), which may act in concert with miR-101 (Varambally et al. 2008). Finally and interestingly, c-MYC is known to drive tumourigenesis by increasing genomic instability by means of single nucleotide substitutions and double-stranded breaks (Prochownik 2008). Thus, c-MYC can alter miR expression either directly by modulating miR promoters or indirectly by inducing genetic alterations that can result in aberrant miR levels. Speculatively, the strong enrichment of prostate cancer-associated miRs among MYC-regulated miRs might be more than a mere coincidence.

\section{miRs towards clinical biochemistry and therapeutics}

Despite much progress, our understanding of miR alterations in prostate cancer is still in its infancy. Once a clearer overview of the pathological significance of each alteration is reached and the statistical value of any deregulation is confirmed in a vast cohort of patients, selected miRs might be appealing candidates for clinical biochemistry and therapeutics. First, miRs have an unusually high stability in formalin-fixed tissues (Li et al. 2007, Xi et al. 2007), and this feature makes their detection by in situ hybridization or quantitative PCR analysis possible. Secondly and more interestingly, miRs have proven to be present in a markedly stable form in the plasma and serum fluids of humans and other animals. The levels of miRs in serum are reproducible and consistent among individuals of the same species (Gilad et al. 2008), while specific expression patterns of serum miRs have already been identified for pregnancy, diabetes and different cancers, thus providing evidence that serum miRs contain fingerprints distinctive of given conditions (Chen et al. 2008, Lawrie et al. 2008, Taylor \& Gercel-Taylor 2008). The comparison of a case-control cohort of serum samples collected from 25 individuals with metastatic prostate cancer and 25 age-matched male control individuals showed increased expression of $m i R-100, m i R-125 b, m i R-141, m i R-143$ and $m i R-296$ in the prostate cancer serum pool (Mitchell et al. 2008). In particular, $m i R-141$ was proven to be the best prostate cancer biomarker, with it being 46-fold up-regulated and expressed in an epithelial cell type-specific manner. Thus, serum miRs hold special promise for the discovery of powerful and sensitive biomarkers, which are easily detectable in non-invasive assays that might overtake the antibody-related drawbacks of proteomics approaches (Rifai et al. 2006). As stated previously, diagnostic, prognostic, predictive and therapeutic markers are needed to help in forecasting disease severity, choosing therapies and monitoring responses. Moreover, unpredictable advances may come from the investigation of a putative functional role of these circulating miRs. The most compelling hypothesis envisages that these small RNAs, packed in microvesicles called exosomes, work as extracellular messengers mediating a new form of cell-cell communication (Valadi et al. 2007). Speculatively, miRs may play a role in the crosstalk between the primary tumour site and the premetastatic microenvironment.

Finally, discovering miRs and their role in the pathogenesis of cancer and other diseases has opened a new biomedical scenario that could use miR agonists or antagonists in order to restore or block the function of a given miR. The multitargeting nature of miRs makes them both powerful and difficult to handle, given the risk of unintended off-target effects that need to be carefully evaluated. The development of antagomiRs, specific and effective miR antagonists that are suitable in vivo, paved the way to miR-based therapeutic strategies (Krutzfeldt et al. 2005, 2007). The first therapeutic application of antagomiRs has proven promising: in mice and non-human primates, the effective and non-toxic antisense-mediated blocking of liver-specific $m i R-122$ resulted in reduced cholesterol synthesis and improved fatty acid metabolism (Elmen et al. 2008). Nonetheless, the undeniable appeal of these results cannot ignore that the pharmacokinetics of any non-tissue-specific miR in organs less receptive than liver, such as prostate, may prove more challenging (Petri et al. 2009). Similarly, the in vivo reintroduction of deficient miRs is a major therapeutic hurdle. Several strategies have been developed to increase small RNA half-life in the blood, facilitate transduction across biological membranes and mediate cell-specific delivery of siRNA (Muratovska \& Eccles 2004). miR-based therapies may take advantage of such strategies.

In conclusion, our knowledge of miRs in cancer is still limited, and much inconsistency of data has to be overcome before a diagnostic and/or therapeutic application of miRs can be envisaged. However, the rapid expansion of this field and the extent of the perspectives offered let us foresee exciting future advances. 


\section{Declaration of interest}

The authors declare that there is no conflict of interest that could be perceived as prejudicing the impartiality of the research reported.

\section{Funding}

We thank the Italian Ministry of Health for supporting the prostate cancer microRNA research (Under-40 years researcher 2007, comma 814; Italy-USA Onco-proteomic 2007-2010).

\section{Acknowledgements}

We thank Dr Ann Zeuner and Tobias Haas for critical reading of the manuscript. We are grateful to Giuseppe Loreto for valuable graphical assistance.

\section{References}

Adhikary S \& Eilers M 2005 Transcriptional regulation and transformation by Myc proteins. Nature Reviews. Molecular Cell Biology 6 635-645.

Akashi T, Koizumi K, Tsuneyama K, Saiki I, Takano Y \& Fuse H 2008 Chemokine receptor CXCR4 expression and prognosis in patients with metastatic prostate cancer. Cancer Science 99 539-542.

Almeida M, Han L, Bellido T, Manolagas SC \& Kousteni S $2005 \mathrm{Wnt}$ proteins prevent apoptosis of both uncommitted osteoblast progenitors and differentiated osteoblasts by beta-catenin-dependent and -independent signaling cascades involving Src/ERK and phosphatidylinositol 3-kinase/AKT. Journal of Biological Chemistry 280 41342-41351.

Ambs S, Prueitt RL, Yi M, Hudson RS, Howe TM, Petrocca F, Wallace TA, Liu CG, Volinia S, Calin GA et al. 2008 Genomic profiling of microRNA and messenger RNA reveals deregulated microRNA expression in prostate cancer. Cancer Research 68 6162-6170.

Arbuzova A, Schmitz AA \& Vergeres G 2002 Cross-talk unfolded: MARCKS proteins. Biochemical Journal 362 1-12.

Asangani IA, Rasheed SA, Nikolova DA, Leupold JH, Colburn NH, Post S \& Allgayer H 2008 MicroRNA-21 (miR-21) post-transcriptionally downregulates tumor suppressor Pdcd4 and stimulates invasion, intravasation and metastasis in colorectal cancer. Oncogene $\mathbf{2 7}$ 2128-2136.

Baltimore D, Boldin MP, O'Connell RM, Rao DS \& Taganov KD 2008 MicroRNAs: new regulators of immune cell development and function. Nature Immunology 9 839-845.

Bartel DP 2004 MicroRNAs: genomics, biogenesis, mechanism, and function. Cell 116 281-297.

Bernard D, Pourtier-Manzanedo A, Gil J \& Beach DH 2003 Myc confers androgen-independent prostate cancer cell growth. Journal of Clinical Investigation 112 1724-1731.
Bommer GT, Gerin I, Feng Y, Kaczorowski AJ, Kuick R, Love RE, Zhai Y, Giordano TJ, Qin ZS, Moore BB et al. 2007 p53-mediated activation of miRNA34 candidate tumor-suppressor genes. Current Biology 17 1298-1307.

Bonci D, Coppola V, Musumeci M, Addario A, Giuffrida R, Memeo L, D'Urso L, Pagliuca A, Biffoni M, Labbaye C et al. 2008 The miR-15a-miR-16-1 cluster controls prostate cancer by targeting multiple oncogenic activities. Nature Medicine 14 1271-1277.

Bourguignon LY, Singleton PA, Zhu H \& Diedrich F 2003 Hyaluronan-mediated CD44 interaction with RhoGEF and Rho kinase promotes Grb2-associated binder-1 phosphorylation and phosphatidylinositol 3-kinase signaling leading to cytokine (macrophage-colony stimulating factor) production and breast tumor progression. Journal of Biological Chemistry 278 29420-29434.

Bracken AP, Pasini D, Capra M, Prosperini E, Colli E \& Helin K 2003 EZH2 is downstream of the pRB-E2F pathway, essential for proliferation and amplified in cancer. EMBO Journal 22 5323-5335.

Brookman-Amissah N, Nariculam J, Freeman A, Willamson M, Kirby RS, Masters JR \& Feneley MR 2007 Allelic imbalance at 13q14.2 approximately q14.3 in localized prostate cancer is associated with early biochemical relapse. Cancer Genetics and Cytogenetics 179 118-126.

Bushati N \& Cohen SM 2007 microRNA functions. Annual Review of Cell and Development Biology 23 175-205.

Bushati N \& Cohen SM 2008 MicroRNAs in neurodegeneration. Current Opinion in Neurobiology 18 292-296.

Calin GA, Dumitru CD, Shimizu M, Bichi R, Zupo S, Noch E, Aldler H, Rattan S, Keating M, Rai K et al. 2002 Frequent deletions and down-regulation of micro-RNA genes miR15 and miR16 at 13q14 in chronic lymphocytic leukemia. PNAS 99 15524-15529.

Calin GA, Sevignani C, Dumitru CD, Hyslop T, Noch E, Yendamuri S, Shimizu M, Rattan S, Bullrich F, Negrini M et al. 2004 Human microRNA genes are frequently located at fragile sites and genomic regions involved in cancers. PNAS 101 2999-3004.

Cao Q, Yu J, Dhanasekaran SM, Kim JH, Mani RS, Tomlins SA, Mehra R, Laxman B, Cao X, Kleer CG et al. 2008 Repression of E-cadherin by the polycomb group protein EZH2 in cancer. Oncogene 27 7274-7284.

Chang TC, Wentzel EA, Kent OA, Ramachandran K, Mullendore M, Lee KH, Feldmann G, Yamakuchi M, Ferlito M, Lowenstein CJ et al. 2007 Transactivation of miR-34a by p53 broadly influences gene expression and promotes apoptosis. Molecular Cell 26 745-752.

Chang TC, Yu D, Lee YS, Wentzel EA, Arking DE, West KM, Dang CV, Thomas-Tikhonenko A \& Mendell JT 2008 Widespread microRNA repression by Myc contributes to tumorigenesis. Nature Genetics 40 43-50.

Chen K \& Rajewsky N 2007 The evolution of gene regulation by transcription factors and microRNAs. Nature Reviews. Genetics 8 93-103. 
Chen C, Frierson HF Jr, Haggerty PF, Theodorescu D, Gregory CW \& Dong JT 2001 An 800-kb region of deletion at $13 q 14$ in human prostate and other carcinomas. Genomics 77 135-144.

Chen X, Ba Y, Ma L, Cai X, Yin Y, Wang K, Guo J, Zhang Y, Chen J, Guo X et al. 2008 Characterization of microRNAs in serum: a novel class of biomarkers for diagnosis of cancer and other diseases. Cell Research 18 997-1006.

Ciafre SA, Galardi S, Mangiola A, Ferracin M, Liu CG, Sabatino G, Negrini M, Maira G, Croce CM \& Farace MG 2005 Extensive modulation of a set of microRNAs in primary glioblastoma. Biochemical and Biophysical Research Communications 334 1351-1358.

Cimmino A, Calin GA, Fabbri M, Iorio MV, Ferracin M, Shimizu M, Wojcik SE, Aqeilan RI, Zupo S, Dono M et al. $2005 \mathrm{miR}-15$ and miR-16 induce apoptosis by targeting BCL2. PNAS 102 13944-13949.

Colombel M, Symmans F, Gil S, O’Toole KM, Chopin D, Benson M, Olsson CA, Korsmeyer S \& Buttyan R 1993 Detection of the apoptosis-suppressing oncoprotein bc1-2 in hormone-refractory human prostate cancers. American Journal of Pathology 143 390-400.

Craft N, Shostak Y, Carey M \& Sawyers CL 1999 A mechanism for hormone-independent prostate cancer through modulation of androgen receptor signaling by the HER-2/neu tyrosine kinase. Nature Medicine 5 280-285.

Culig Z, Steiner H, Bartsch G \& Hobisch A 2005 Interleukin-6 regulation of prostate cancer cell growth. Journal of Cellular Biochemistry 95 497-505.

Cullen BR 2009 Viral and cellular messenger RNA targets of viral microRNAs. Nature 457 421-425.

Dahiya N, Sherman-Baust CA, Wang TL, Davidson B, Shih Ie M, Zhang Y, Wood W III, Becker KG \& Morin PJ 2008 MicroRNA expression and identification of putative miRNA targets in ovarian cancer. PLOS ONE 3 e2436.

Damber JE \& Aus G 2008 Prostate cancer. Lancet 371 1710-1721.

Dong JT 2001 Chromosomal deletions and tumor suppressor genes in prostate cancer. Cancer Metastasis Reviews 20 173-193.

Elmen J, Lindow M, Schutz S, Lawrence M, Petri A, Obad S, Lindholm M, Hedtjarn M, Hansen HF, Berger U et al. 2008 LNA-mediated microRNA silencing in non-human primates. Nature 452 896-899.

Felicetti F, Errico MC, Bottero L, Segnalini P, Stoppacciaro A, Biffoni M, Felli N, Mattia G, Petrini M, Colombo MP et al. 2008 The promyelocytic leukemia zinc fingermicroRNA-221/-222 pathway controls melanoma progression through multiple oncogenic mechanisms. Cancer Research 68 2745-2754.

Fornari F, Gramantieri L, Ferracin M, Veronese A, Sabbioni S, Calin GA, Grazi GL, Giovannini C, Croce CM, Bolondi L et al. $2008 \mathrm{MiR}-221$ controls CDKN1C/p57 and $\mathrm{CDKN} 1 \mathrm{~B} / \mathrm{p} 27$ expression in human hepatocellular carcinoma. Oncogene 27 5651-5661.
Frankel LB, Christoffersen NR, Jacobsen A, Lindow M, Krogh A \& Lund AH 2008 Programmed cell death 4 (PDCD4) is an important functional target of the microRNA miR-21 in breast cancer cells. Journal of Biological Chemistry 283 1026-1033.

Fujita Y, Kojima K, Hamada N, Ohhashi R, Akao Y, Nozawa Y, Deguchi T \& Ito M 2008 Effects of miR-34a on cell growth and chemoresistance in prostate cancer PC3 cells. Biochemical and Biophysical Research Communications 377 114-119.

Fulci V, Chiaretti S, Goldoni M, Azzalin G, Carucci N, Tavolaro S, Castellano L, Magrelli A, Citarella F, Messina M et al. 2007 Quantitative technologies establish a novel microRNA profile of chronic lymphocytic leukemia. Blood 109 4944-4951.

Gabriely G, Wurdinger T, Kesari S, Esau CC, Burchard J, Linsley PS \& Krichevsky AM 2008 MicroRNA 21 promotes glioma invasion by targeting matrix metalloproteinase regulators. Molecular and Cellular Biology 28 5369-5380.

Galardi S, Mercatelli N, Giorda E, Massalini S, Frajese GV, Ciafre SA \& Farace MG 2007 miR-221 and miR-222 expression affects the proliferation potential of human prostate carcinoma cell lines by targeting p27Kip1. Journal of Biological Chemistry 282 23716-23724.

Gandellini P, Folini M, Longoni N, Pennati M, Binda M, Colecchia M, Salvioni R, Supino R, Moretti R, Limonta P et al. 2009 miR-205 Exerts tumor-suppressive functions in human prostate through down-regulation of protein kinase Cepsilon. Cancer Research 69 2287-2295.

Gangaraju VK \& Lin H 2009 MicroRNAs: key regulators of stem cells. Nature Reviews. Molecular Cell Biology 10 116-125.

Gao P, Tchernyshyov I, Chang TC, Lee YS, Kita K, Ochi T, Zeller KI, De Marzo AM, Van Eyk JE, Mendell JT et al. 2009 c-Myc suppression of miR-23a/b enhances mitochondrial glutaminase expression and glutamine metabolism. Nature 458 762-765.

Gilad S, Meiri E, Yogev Y, Benjamin S, Lebanony D, Yerushalmi N, Benjamin H, Kushnir M, Cholakh H, Melamed N et al. 2008 Serum microRNAs are promising novel biomarkers. PLOS ONE 3 e3148.

Gottardo F, Liu CG, Ferracin M, Calin GA, Fassan M, Bassi P, Sevignani C, Byrne D, Negrini M, Pagano F et al. 2007 Micro-RNA profiling in kidney and bladder cancers. Urologic Oncology 25 387-392.

Graff JR, Konicek BW, McNulty AM, Wang Z, Houck K, Allen S, Paul JD, Hbaiu A, Goode RG, Sandusky GE et al. 2000 Increased AKT activity contributes to prostate cancer progression by dramatically accelerating prostate tumor growth and diminishing p27Kip1 expression. Journal of Biological Chemistry 275 24500-24505.

Gronberg H 2003 Prostate cancer epidemiology. Lancet 361 859-864.

He L \& Hannon GJ 2004 MicroRNAs: small RNAs with a big role in gene regulation. Nature Reviews. Genetics $\mathbf{5}$ 522-531. 
He L, He X, Lim LP, de Stanchina E, Xuan Z, Liang Y, Xue W, Zender L, Magnus J, Ridzon D et al. 2007 A microRNA component of the p53 tumour suppressor network. Nature 447 1130-1134.

Hutvagner G, McLachlan J, Pasquinelli AE, Balint E, Tuschl T \& Zamore PD 2001 A cellular function for the RNA-interference enzyme Dicer in the maturation of the let-7 small temporal RNA. Science 293 834-838.

Iorio MV, Visone R, Di Leva G, Donati V, Petrocca F, Casalini P, Taccioli C, Volinia S, Liu CG, Alder H et al. 2007 MicroRNA signatures in human ovarian cancer. Cancer Research 67 8699-8707.

Itoh K, Yoshioka K, Akedo H, Uehata M, Ishizaki T \& Narumiya S 1999 An essential part for Rho-associated kinase in the transcellular invasion of tumor cells. Nature Medicine 5 221-225.

Iwai N \& Naraba H 2005 Polymorphisms in human pre-miRNAs. Biochemical and Biophysical Research Communications 331 1439-1444.

Jenkins RB, Qian J, Lieber MM \& Bostwick DG 1997 Detection of c-myc oncogene amplification and chromosomal anomalies in metastatic prostatic carcinoma by fluorescence in situ hybridization. Cancer Research 57 524-531.

Jongen-Lavrencic M, Sun SM, Dijkstra MK, Valk PJ \& Lowenberg B 2008 MicroRNA expression profiling in relation to the genetic heterogeneity of acute myeloid leukemia. Blood 111 5078-5085.

Josson S, Sung SY, Lao K, Chung LW \& Johnstone PA 2008 Radiation modulation of microRNA in prostate cancer cell lines. Prostate 68 1599-1606.

Karaa ZS, Iacovoni JS, Bastide A, Lacazette E, Touriol C \& Prats H 2009 The VEGF IRESes are differentially susceptible to translation inhibition by miR-16. RNA 15 249-254.

Karube Y, Tanaka H, Osada H, Tomida S, Tatematsu Y, Yanagisawa K, Yatabe Y, Takamizawa J, Miyoshi S, Mitsudomi T et al. 2005 Reduced expression of Dicer associated with poor prognosis in lung cancer patients. Cancer Science 96 111-115.

Ketting RF, Fischer SE, Bernstein E, Sijen T, Hannon GJ \& Plasterk RH 2001 Dicer functions in RNA interference and in synthesis of small RNA involved in developmental timing in C. elegans. Genes and Development 15 2654-2659.

Kim YK, Yu J, Han TS, Park SY, Namkoong B, Kim DH, Hur K, Yoo MW, Lee HJ, Yang HK et al. 2009 Functional links between clustered microRNAs: suppression of cellcycle inhibitors by microRNA clusters in gastric cancer. Nucleic Acids Research 37 1672-1681.

Krutzfeldt J, Rajewsky N, Braich R, Rajeev KG, Tuschl T, Manoharan M \& Stoffel M 2005 Silencing of microRNAs in vivo with 'antagomirs'. Nature 438 685-689.

Krutzfeldt J, Kuwajima S, Braich R, Rajeev KG, Pena J, Tuschl T, Manoharan M \& Stoffel M 2007 Specificity, duplex degradation and subcellular localization of antagomirs. Nucleic Acids Research 35 2885-2892.

Kucia M, Reca R, Miekus K, Wanzeck J, Wojakowski W, Janowska-Wieczorek A, Ratajczak J \& Ratajczak MZ 2005 Trafficking of normal stem cells and metastasis of cancer stem cells involve similar mechanisms: pivotal role of the SDF-1-CXCR4 axis. Stem Cells $\mathbf{2 3}$ 879-894.

Kulshreshtha R, Ferracin M, Wojcik SE, Garzon R, Alder H, Agosto-Perez FJ, Davuluri R, Liu CG, Croce CM, Negrini $\mathrm{M}$ et al. 2007 A microRNA signature of hypoxia. Molecular and Cellular Biology 27 1859-1867.

Kutay H, Bai S, Datta J, Motiwala T, Pogribny I, Frankel W, Jacob ST \& Ghoshal K 2006 Downregulation of miR-122 in the rodent and human hepatocellular carcinomas. Journal of Cellular Biochemistry 99 671-678.

Labbaye C, Spinello I, Quaranta MT, Pelosi E, Pasquini L, Petrucci E, Biffoni M, Nuzzolo ER, Billi M, Foa R et al. 2008 A three-step pathway comprising PLZF/miR146a/CXCR4 controls megakaryopoiesis. Nature Cell Biology 10 788-801.

Latil A, Bieche I, Pesche S, Volant A, Valeri A, Fournier G, Cussenot O \& Lidereau R 1999 Loss of heterozygosity at chromosome arm 13q and RB1 status in human prostate cancer. Human Pathology 30 809-815.

Latil A, Morant P, Fournier G, Mangin P, Berthon P \& Cussenot O 2002 CHC1-L, a candidate gene for prostate carcinogenesis at $13 q 14.2$, is frequently affected by loss of heterozygosity and underexpressed in human prostate cancer. International Journal of Cancer 99 689-696.

Latronico MV \& Condorelli G 2009 MicroRNAs and cardiac pathology. Nature Reviews. Cardiology 6 419-429.

Lawrie CH 2007 MicroRNA expression in lymphoma. Expert Opinion on Biological Therapy 7 1363-1374.

Lawrie CH, Chi J, Taylor S, Tramonti D, Ballabio E, Palazzo S, Saunders NJ, Pezzella F, Boultwood J, Wainscoat JS et al. 2008 Expression of MicroRNAs in diffuse large B cell lymphoma is associated with immunophenotype, survival, and transformation from follicular lymphoma. Journal of Cellular and Molecular Medicine 13 1248-1260.

Lee Y, Ahn C, Han J, Choi H, Kim J, Yim J, Lee J, Provost P, Radmark O, Kim S et al. 2003 The nuclear RNase III Drosha initiates microRNA processing. Nature $\mathbf{4 2 5}$ 415-419.

Lee Y, Kim M, Han J, Yeom KH, Lee S, Baek SH \& Kim VN 2004 MicroRNA genes are transcribed by RNA polymerase II. EMBO Journal 23 4051-4060.

Lee EJ, Gusev Y, Jiang J, Nuovo GJ, Lerner MR, Frankel WL, Morgan DL, Postier RG, Brackett DJ \& Schmittgen TD 2007 Expression profiling identifies microRNA signature in pancreatic cancer. International Journal of Cancer 120 1046-1054.

Lewis BP, Burge CB \& Bartel DP 2005 Conserved seed pairing, often flanked by adenosines, indicates that thousands of human genes are microRNA targets. Cell 120 15-20. 
Li F, Wang Y, Zeller KI, Potter JJ, Wonsey DR, O'Donnell KA, Kim JW, Yustein JT, Lee LA \& Dang CV 2005 Myc stimulates nuclearly encoded mitochondrial genes and mitochondrial biogenesis. Molecular and Cellular Biology 25 6225-6234.

Li Z, Szabolcs M, Terwilliger JD \& Efstratiadis A 2006 Prostatic intraepithelial neoplasia and adenocarcinoma in mice expressing a probasin-Neu oncogenic transgene. Carcinogenesis 27 1054-1067.

Li J, Smyth P, Flavin R, Cahill S, Denning K, Aherne S, Guenther SM, O'Leary JJ \& Sheils O 2007 Comparison of miRNA expression patterns using total RNA extracted from matched samples of formalin-fixed paraffinembedded (FFPE) cells and snap frozen cells. BMC Biotechnology 736.

Li T, Li D, Sha J, Sun P \& Huang Y 2009 MicroRNA-21 directly targets MARCKS and promotes apoptosis resistance and invasion in prostate cancer cells. Biochemical and Biophysical Research Communications 383 280-285.

Lin SL, Chang D \& Ying SY 2007 Hyaluronan stimulates transformation of androgen-independent prostate cancer. Carcinogenesis 28 310-320.

Lin SL, Chiang A, Chang D \& Ying SY 2008 Loss of mir-146a function in hormone-refractory prostate cancer. RNA 14 417-424.

Linsley PS, Schelter J, Burchard J, Kibukawa M, Martin MM, Bartz SR, Johnson JM, Cummins JM, Raymond CK, Dai H et al. 2007 Transcripts targeted by the microRNA-16 family cooperatively regulate cell cycle progression. Molecular and Cellular Biology 27 2240-2252.

Liu Q, Fu H, Sun F, Zhang H, Tie Y, Zhu J, Xing R, Sun Z \& Zheng X 2008 miR-16 family induces cell cycle arrest by regulating multiple cell cycle genes. Nucleic Acids Research 36 5391-5404.

Loeb S \& Catalona WJ 2007 Prostate-specific antigen in clinical practice. Cancer Letters 249 30-39.

Lu J, Getz G, Miska EA, Alvarez-Saavedra E, Lamb J, Peck D, Sweet-Cordero A, Ebert BL, Mak RH, Ferrando AA et al. 2005 MicroRNA expression profiles classify human cancers. Nature 435 834-838.

Lui WO, Pourmand N, Patterson BK \& Fire A 2007 Patterns of known and novel small RNAs in human cervical cancer. Cancer Research 67 6031-6043.

Lujambio A, Ropero S, Ballestar E, Fraga MF, Cerrato C, Setien F, Casado S, Suarez-Gauthier A, SanchezCespedes M, Git A et al. 2007 Genetic unmasking of an epigenetically silenced microRNA in human cancer cells. Cancer Research 67 1424-1429.

Luker KE \& Luker GD 2006 Functions of CXCL12 and CXCR4 in breast cancer. Cancer Letters 238 30-41.

Mayr C, Hemann MT \& Bartel DP 2007 Disrupting the pairing between let-7 and Hmga2 enhances oncogenic transformation. Science 315 1576-1579.

McDonnell TJ, Troncoso P, Brisbay SM, Logothetis C, Chung LW, Hsieh JT, Tu SM \& Campbell ML 1992
Expression of the protooncogene bcl-2 in the prostate and its association with emergence of androgenindependent prostate cancer. Cancer Research 52 6940-6944.

Mendell JT 2008 miRiad roles for the miR-17-92 cluster in development and disease. Cell 133 217-222.

Meng F, Henson R, Wehbe-Janek H, Ghoshal K, Jacob ST \& Patel T 2007 MicroRNA-21 regulates expression of the PTEN tumor suppressor gene in human hepatocellular cancer. Gastroenterology 133 647-658.

Mercatelli N, Coppola V, Bonci D, Miele F, Costantini A, Guadagnoli M, Bonanno E, Muto G, Frajese GV, De Maria R et al. 2008 The inhibition of the highly expressed miR-221 and miR-222 impairs the growth of prostate carcinoma xenografts in mice. PLOS ONE 3 e4029.

Meyer N \& Penn LZ 2008 Reflecting on 25 years with MYC. Nature Reviews. Cancer 8 976-990.

Mitchell PS, Parkin RK, Kroh EM, Fritz BR, Wyman SK, Pogosova-Agadjanyan EL, Peterson A, Noteboom J, O'Briant KC, Allen A et al. 2008 Circulating microRNAs as stable blood-based markers for cancer detection. PNAS 105 10513-10518.

Mochizuki H, Matsubara A, Teishima J, Mutaguchi K, Yasumoto H, Dahiya R, Usui T \& Kamiya K 2004 Interaction of ligand-receptor system between stromalcell-derived factor- 1 and $\mathrm{CXC}$ chemokine receptor 4 in human prostate cancer: a possible predictor of metastasis. Biochemical and Biophysical Research Communications 320 656-663.

Muratovska A \& Eccles MR 2004 Conjugate for efficient delivery of short interfering RNA (siRNA) into mammalian cells. FEBS Letters 558 63-68.

Musiyenko A, Bitko V \& Barik S 2008 Ectopic expression of miR-126*, an intronic product of the vascular endothelial EGF-like 7 gene, regulates prostein translation and invasiveness of prostate cancer LNCaP cells. Journal of Molecular Medicine 86 313-322.

Nam EJ \& Kim YT 2008 Alteration of cell-cycle regulation in epithelial ovarian cancer. International Journal of Gynecological Cancer 18 1169-1182.

Navarro A, Gaya A, Martinez A, Urbano-Ispizua A, Pons A, Balague O, Gel B, Abrisqueta P, Lopez-Guillermo A, Artells R et al. 2008 MicroRNA expression profiling in classic Hodgkin lymphoma. Blood 111 2825-2832.

Noonan EJ, Place RF, Pookot D, Basak S, Whitson JM, Hirata H, Giardina C \& Dahiya R 2009 miR-449a targets HDAC-1 and induces growth arrest in prostate cancer. Oncogene 28 1714-1724.

Nupponen NN, Hyytinen ER, Kallioniemi AH \& Visakorpi T $1998 a$ Genetic alterations in prostate cancer cell lines detected by comparative genomic hybridization. Cancer Genetics and Cytogenetics 101 53-57.

Nupponen NN, Kakkola L, Koivisto P \& Visakorpi T $1998 b$ Genetic alterations in hormone-refractory recurrent prostate carcinomas. American Journal of Pathology $153141-148$. 
O’Donnell KA, Wentzel EA, Zeller KI, Dang CV \& Mendell JT 2005 c-Myc-regulated microRNAs modulate E2F1 expression. Nature 435 839-843.

Ozen M, Creighton CJ, Ozdemir M \& Ittmann M 2008 Widespread deregulation of microRNA expression in human prostate cancer. Oncogene 27 1788-1793.

Pallante P, Visone R, Ferracin M, Ferraro A, Berlingieri MT, Troncone G, Chiappetta G, Liu CG, Santoro M, Negrini M et al. 2006 MicroRNA deregulation in human thyroid papillary carcinomas. Endocrine-Related Cancer 13 497-508.

Peinado H, Olmeda D \& Cano A 2007 Snail, Zeb and bHLH factors in tumour progression: an alliance against the epithelial phenotype? Nature Reviews. Cancer 7 415-428.

Peters L \& Meister G 2007 Argonaute proteins: mediators of RNA silencing. Molecular Cell 26 611-623.

Petri A, Lindow M \& Kauppinen S 2009 MicroRNA silencing in primates: towards development of novel therapeutics. Cancer Research 69 393-395.

Porkka KP \& Visakorpi T 2004 Molecular mechanisms of prostate cancer. European Urology 45 683-691.

Porkka KP, Pfeiffer MJ, Waltering KK, Vessella RL, Tammela TL \& Visakorpi T 2007 MicroRNA expression profiling in prostate cancer. Cancer Research 67 6130-6135.

Prochownik EV 2008 c-Myc: linking transformation and genomic instability. Current Molecular Medicine $\mathbf{8}$ 446-458.

Qian DZ, Wei YF, Wang X, Kato Y, Cheng L \& Pili R 2007 Antitumor activity of the histone deacetylase inhibitor MS-275 in prostate cancer models. Prostate 67 1182-1193.

Raver-Shapira N, Marciano E, Meiri E, Spector Y, Rosenfeld N, Moskovits N, Bentwich Z \& Oren M 2007 Transcriptional activation of miR-34a contributes to p53-mediated apoptosis. Molecular Cell 26 731-743.

Reiter RE, Sato I, Thomas G, Qian J, Gu Z, Watabe T, Loda M \& Jenkins RB 2000 Coamplification of prostate stem cell antigen (PSCA) and MYC in locally advanced prostate cancer. Genes, Chromosomes \& Cancer 27 95-103.

Ren B, Yu G, Tseng GC, Cieply K, Gavel T, Nelson J, Michalopoulos G, Yu YP \& Luo JH 2006 MCM7 amplification and overexpression are associated with prostate cancer progression. Oncogene 25 1090-1098.

Rifai N, Gillette MA \& Carr SA 2006 Protein biomarker discovery and validation: the long and uncertain path to clinical utility. Nature Biotechnology 24 971-983.

Rodriguez A, Griffiths-Jones S, Ashurst JL \& Bradley A 2004 Identification of mammalian microRNA host genes and transcription units. Genome Research 14 1902-1910.

Saito Y, Liang G, Egger G, Friedman JM, Chuang JC, Coetzee GA \& Jones PA 2006 Specific activation of microRNA-127 with downregulation of the protooncogene BCL6 by chromatin-modifying drugs in human cancer cells. Cancer Cell 9 435-443.
Sampath D, Calin GA, Puduvalli VK, Gopisetty G, Taccioli C, Liu CG, Ewald B, Liu C, Keating MJ \& Plunkett W 2009 Specific activation of microRNA106b enables the p73 apoptotic response in chronic lymphocytic leukemia by targeting the ubiquitin ligase Itch for degradation. Blood 113 3744-3753.

Sander S, Bullinger L, Klapproth K, Fiedler K, Kestler HA, Barth TF, Moller P, Stilgenbauer S, Pollack JR \& Wirth T 2008 MYC stimulates EZH2 expression by repression of its negative regulator miR-26a. Blood 112 4202-4212.

Saramaki OR, Porkka KP, Vessella RL \& Visakorpi T 2006 Genetic aberrations in prostate cancer by microarray analysis. International Journal of Cancer 119 1322-1329.

Sayed D, Rane S, Lypowy J, He M, Chen IY, Vashistha H, Yan L, Malhotra A, Vatner D \& Abdellatif M 2008 MicroRNA-21 targets Sprouty2 and promotes cellular outgrowths. Molecular Biology of the Cell 19 3272-3282.

Schweizer L, Rizzo CA, Spires TE, Platero JS, Wu Q, Lin TA, Gottardis MM \& Attar RM 2008 The androgen receptor can signal through Wnt/beta-Catenin in prostate cancer cells as an adaptation mechanism to castration levels of androgens. BMC Cell Biology 94.

Scott GK, Goga A, Bhaumik D, Berger CE, Sullivan CS \& Benz CC 2007 Coordinate suppression of ERBB2 and ERBB3 by enforced expression of micro-RNA miR-125a or miR-125b. Journal of Biological Chemistry 282 1479-1486.

Shi XB, Xue L, Yang J, Ma AH, Zhao J, Xu M, Tepper CG, Evans CP, Kung HJ \& deVere White RW 2007 An androgen-regulated miRNA suppresses Bak1 expression and induces androgen-independent growth of prostate cancer cells. PNAS 104 19983-19988.

Shin S, Cha HJ, Lee EM, Jung JH, Lee SJ, Park IC, Jin YW \& An S 2009 MicroRNAs are significantly influenced by p53 and radiation in HCT116 human colon carcinoma cells. International Journal of Oncology 34 1645-1652.

Stefani G \& Slack FJ 2008 Small non-coding RNAs in animal development. Nature Reviews. Molecular Cell Biology 9 219-230.

Sugito N, Ishiguro H, Kuwabara Y, Kimura M, Mitsui A, Kurehara H, Ando T, Mori R, Takashima N, Ogawa R et al. 2006 RNASEN regulates cell proliferation and affects survival in esophageal cancer patients. Clinical Cancer Research 12 7322-7328.

Sun YX, Wang J, Shelburne CE, Lopatin DE, Chinnaiyan AM, Rubin MA, Pienta KJ \& Taichman RS 2003 Expression of CXCR4 and CXCL12 (SDF-1) in human prostate cancers (PCa) in vivo. Journal of Cellular Biochemistry $89462-473$.

Sun R, Fu X, Li Y, Xie Y \& Mao Y 2009a Global gene expression analysis reveals reduced abundance of putative microRNA targets in human prostate tumours. $B M C$ Genomics 1093.

Sun T, Wang Q, Balk S, Brown M, Lee GS \& Kantoff P $2009 b$ The role of microRNA-221 and microRNA-222 in androgen-independent prostate cancer cell lines. Cancer Research 69 3356-3363. 
Sylvestre Y, De Guire V, Querido E, Mukhopadhyay UK, Bourdeau V, Major F, Ferbeyre G \& Chartrand P 2007 An E2F/miR-20a autoregulatory feedback loop. Journal of Biological Chemistry 282 2135-2143.

Taylor DD \& Gercel-Taylor C 2008 MicroRNA signatures of tumor-derived exosomes as diagnostic biomarkers of ovarian cancer. Gynecological Oncology 110 13-21.

Tazawa H, Tsuchiya N, Izumiya M \& Nakagama H 2007 Tumor-suppressive miR-34a induces senescence-like growth arrest through modulation of the E2F pathway in human colon cancer cells. PNAS 104 15472-15477.

Tetzlaff MT, Liu A, Xu X, Master SR, Baldwin DA, Tobias JW, Livolsi VA \& Baloch ZW 2007 Differential expression of miRNAs in papillary thyroid carcinoma compared to multinodular goiter using formalin fixed paraffin embedded tissues. Endocrine Pathology 18 163-173.

Tong AW, Fulgham P, Jay C, Chen P, Khalil I, Liu S, Senzer N, Eklund AC, Han J \& Nemunaitis J 2009 MicroRNA profile analysis of human prostate cancers. Cancer Gene Therapy 16 206-216.

Tran N, McLean T, Zhang X, Zhao CJ, Thomson JM, O'Brien C \& Rose B 2007 MicroRNA expression profiles in head and neck cancer cell lines. Biochemical and Biophysical Research Communications 358 12-17.

Ueda T, Emi M, Suzuki H, Komiya A, Akakura K, Ichikawa T, Watanabe M, Shiraishi T, Masai M, Igarashi T et al. 1999 Identification of a I-cM region of common deletion on $13 \mathrm{q} 14$ associated with human prostate cancer. Genes, Chromosomes \& Cancer 24 183-190.

Valadi H, Ekstrom K, Bossios A, Sjostrand M, Lee JJ \& Lotvall JO 2007 Exosome-mediated transfer of mRNAs and microRNAs is a novel mechanism of genetic exchange between cells. Nature Cell Biology 9 654-659.

Varambally S, Dhanasekaran SM, Zhou M, Barrette TR, Kumar-Sinha C, Sanda MG, Ghosh D, Pienta KJ, Sewalt RG, Otte AP et al. 2002 The polycomb group protein $\mathrm{EZH} 2$ is involved in progression of prostate cancer. Nature 419 624-629.

Varambally S, Cao Q, Mani RS, Shankar S, Wang X, Ateeq B, Laxman B, Cao X, Jing X, Ramnarayanan K et al. 2008 Genomic loss of microRNA-101 leads to overexpression of histone methyltransferase EZH2 in cancer. Science 322 1695-1699.

Visakorpi T, Kallioniemi AH, Syvanen AC, Hyytinen ER, Karhu R, Tammela T, Isola JJ \& Kallioniemi OP 1995 Genetic changes in primary and recurrent prostate cancer by comparative genomic hybridization. Cancer Research 55 342-347.

Volinia S, Calin GA, Liu CG, Ambs S, Cimmino A, Petrocca F, Visone R, Iorio M, Roldo C, Ferracin M et al. 2006 A microRNA expression signature of human solid tumors defines cancer gene targets. PNAS 103 2257-2261.

Wang J, Loberg R \& Taichman RS 2006 The pivotal role of CXCL12 (SDF-1)/CXCR4 axis in bone metastasis. Cancer Metastasis Reviews 25 573-587.

Wedel SA, Sparatore A, Soldato PD, Al-Batran SE, Atmaca A, Juengel E, Hudak L, Jonas D \& Blaheta RA 2008
New histone deacetylase inhibitors as potential therapeutic tools for advanced prostate carcinoma. Journal of Cellular and Molecular Medicine 12 2457-2466.

Weichert W, Roske A, Gekeler V, Beckers T, Stephan C, Jung K, Fritzsche FR, Niesporek S, Denkert C, Dietel M et al. 2008 Histone deacetylases 1, 2 and 3 are highly expressed in prostate cancer and HDAC2 expression is associated with shorter PSA relapse time after radical prostatectomy. British Journal of Cancer 98 604-610.

Williams TM, Hassan GS, Li J, Cohen AW, Medina F, Frank PG, Pestell RG, Di Vizio D, Loda M \& Lisanti MP 2005 Caveolin-1 promotes tumor progression in an autochthonous mouse model of prostate cancer: genetic ablation of Cav-1 delays advanced prostate tumor development in tramp mice. Journal of Biological Chemistry $\mathbf{2 8 0}$ 25134-25145.

Wu D \& Terrian DM 2002 Regulation of caveolin-1 expression and secretion by a protein kinase cepsilon signaling pathway in human prostate cancer cells. Journal of Biological Chemistry 277 40449-40455.

Wu H, Sun L, Moul JW, Wu HY, McLeod DG, Amling C, Lance R, Kusuda L, Donahue T, Foley J et al. 2004 Watchful waiting and factors predictive of secondary treatment of localized prostate cancer. Journal of Urology 171 1111-1116.

Xi Y, Nakajima G, Gavin E, Morris CG, Kudo K, Hayashi K \& Ju J 2007 Systematic analysis of microRNA expression of RNA extracted from fresh frozen and formalin-fixed paraffin-embedded samples. RNA 13 1668-1674.

Yamakuchi M, Ferlito M \& Lowenstein CJ 2008 miR-34a repression of SIRT1 regulates apoptosis. PNAS $\mathbf{1 0 5}$ 13421-13426.

Yeh S, Lin HK, Kang HY, Thin TH, Lin MF \& Chang C 1999 From HER2/Neu signal cascade to androgen receptor and its coactivators: a novel pathway by induction of androgen target genes through MAP kinase in prostate cancer cells. PNAS 96 5458-5463.

Yin Z, Spitz MR, Babaian RJ, Strom SS, Troncoso P \& Kagan J 1999 Limiting the location of a putative human prostate cancer tumor suppressor gene at chromosome 13q14.3. Oncogene 18 7576-7583.

Yoshino T, Shiina H, Urakami S, Kikuno N, Yoneda T, Shigeno K \& Igawa M 2006 Bcl-2 expression as a predictive marker of hormone-refractory prostate cancer treated with taxane-based chemotherapy. Clinical Cancer Research 12 6116-6124.

Yu J, Cao Q, Mehra R, Laxman B, Tomlins SA, Creighton CJ, Dhanasekaran SM, Shen R, Chen G, Morris DS et al. 2007 Integrative genomics analysis reveals silencing of betaadrenergic signaling by polycomb in prostate cancer. Cancer Cell 12 419-431.

Yun MS, Kim SE, Jeon SH, Lee JS \& Choi KY 2005 Both ERK and $\mathrm{Wnt} /$ beta-catenin pathways are involved in Wnt3ainduced proliferation. Journal of Cell Science 118 313-322.

Zhu S, Si ML, Wu H \& Mo YY 2007 MicroRNA-21 targets the tumor suppressor gene tropomyosin 1 (TPM1).

Journal of Biological Chemistry 282 14328-14336. 